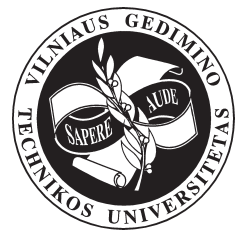

\title{
THE ROLE OF GOVERNMENT IN IMPLEMENTATION OF INNOVATIONS: A CASE OF LITHUANIA
}

\author{
Manuela Tvaronavičiené ${ }^{1}$, Renata Korsakiené ${ }^{2}$ \\ Dept of Enterprise Economics and Business Management, Vilnius Gediminas Technical University, \\ Sauletekio al. 11, LT-10223 Vilnius, Lithuania \\ E-mail:1'manuela@post.omnitel.net; ${ }^{2}$ renatakorsa@takas.lt
}

Received 6 November 2006; accepted 5 January 2007

\begin{abstract}
The paper deals with factors fostering implementation of innovations into Lithuanian economy. Size of enterprises and sectors of economy have been taken into account. The authors strive to estimate the role of government in the process of innovation in the economy. Hence, authors analyse factors fostering implementation of innovations, the role of state aid and perceived efficiency of state policy. At the end of the paper, the results of the survey are summarized and the conclusions are presented. Presented investigation is based on questioning results of business enterprises.
\end{abstract}

Keywords: innovations, government, state aid, state policy.

\section{Introduction}

The importance of innovations in the development of country's economy is recognized in the EU. Hence, hundreds of programmes and support schemes, which strive to foster innovations, have been developed in all Member States. Lithuanian Innovation policy targets Lisbon and Innovation Action Plan objectives. On the other hand, after entering the EU development of Lithuanian National Innovation System has obtained higher importance due to domination of labour intensive industries and moderate share of technology driven industries in Lithuanian economy.

The Innovation in Business Programme is seen as the main part of Lithuanian innovation policy which has foreseen long term goals and main tools allowing reaching these goals. Notably, the enhancement of international competitiveness of private sector companies is set as the long term goal. The programme foresees financial and other support, elimination of obstacles restricting development of innovations and stimulation of cooperation efforts between business companies and scientific institutions.

The strengths of Lithuanian National Innovation System are related to the well developed higher education sector and its strong scientific research traditions. However, the ability of country to support creative innovations requires a large increase of business R\&D and support of public $R \& D$. The low spending on R\&D influenced unsatisfactory level of Lithuania's performance on patenting, and in terms of strategic R\&D based innovation Lithuania ranks last out of 19 countries [1]. Hence, Lithuanian innovation policy is seen as weak and requires taking more active actions of all parts, i.e. business and government.

The aim of this paper is to analyse the role of government in implementation of innovations in Lithuania. Taking into account innovation policy, factors fostering implementation of innovations, the role of State aid and perceived efficiency of State policy are considered. Presented investigation is based on large-scale questioning of business enterprises. Policy implications are seen as main outcome of presented research.

\section{Literature review}

The neoclassical growth theory paid attention to the accumulation of such resources as capital and labour [2]. However, new growth of economics emphasize the need for technological innovations and knowledge spillovers as the major factors of sustainable growth [3]. Freeman and Soete point out that innovation is an essential condition of 
economic progress and important element in the competition of companies [4]. Anyway, the innovative activities of firms not only lead to new products whose benefits firms can appropriate but also cause knowledge spillovers [5].

Notably, Schumpeter proposed the theory of economic development and new value creation through the process of technological change and innovation [6]. Accordingly technological development is seen as discontinuous change and equilibrium resulting from innovation. Anyway, Schumpeter identified such sources of innovation as the introduction of new goods or new production methods, the creation of new markets, the discovery of the new supply sources, and the reorganization of industries. It has to be noted that Schumpeter introduced notion "creative destruction" pointing out that following technological change certain rents become available to entrepreneurs. These rents later diminish as innovations become established practices in economic life [7]. On the other hand early Schumpeterian works emphasized the contribution of individual entrepreneurs $[6,8]$.

According to Schumpeter, innovation is the source of value creation. Notably, the importance of technology is emphasized and novel combinations of resources are considered. Other scholars point out that the effectiveness of protective property rights and complementary assets can add to the value creation potential of innovations [9]. For instance, Moran and Goshal emphasized the role of economic exchange through which the latent value imbedded in the new combination of resources is realizable [10].

Some scholars point out, that among both economists and policymakers, there has long been a continuous support for the view that governments have to take active actions in responding to deficiencies for science and technology in private markets [11]. The government could play a major role within national innovation system due to its significant influence over various economic and institutional factors that determine the economy's capacity to develop and adapt new technology. For instance, the government encourage $R \& D$ through the protection of intellectual rights, tax system, subsidies and procurement of advanced technologies.

OECD observes that "governments need to play an integrating role in managing knowledge on an economy-wide basis by making technology and innovation policy an integral part of overall economic policy" [12]. Hence, the government should refocus specific objectives and adapt the instruments of technology and innovation policy and secure framework conditions that are conducive to innovation.

\section{Survey of business enterprises attitude towards innovations}

In order to indicate approach of business companies towards the role of state support, a survey has been made.

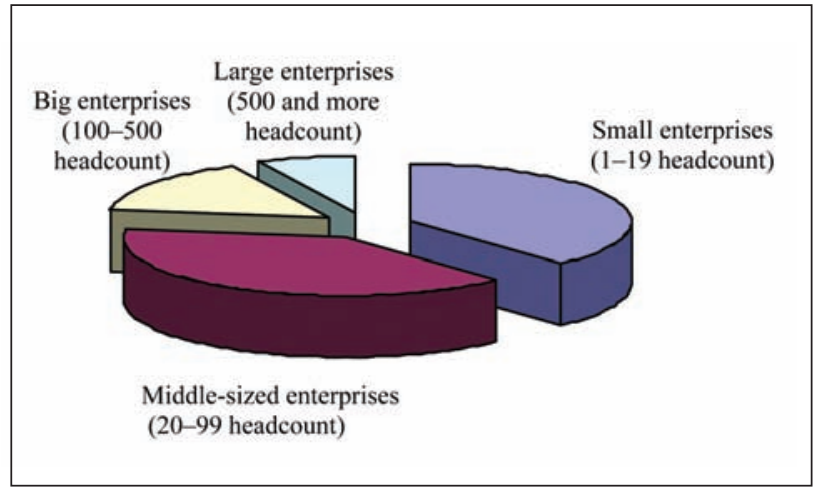

Fig 1. Structure of respondents according to size

The survey is based on responses to a questioner embracing various aspects of innovation implementation process in Lithuanian enterprises. 1264 enterprises from all business sectors in Lithuania participated in the investigation. 1001 responses were considered as acceptable for scientific generalization and were used for deriving tendencies. Companies for queries have been chosen randomly. Their division across sectors of economy is as follows: 715 companies are attributed to service sector and 286, respectively, to industry one (service sector dominates in Lithuanian economy and is less concentrated). Structure of respondents according to size is presented in Fig 1.

Factors fostering implementation of innovations

Striving to assess factors fostering implementation of innovations, respondents were asked to evaluate the role of suppliers, clients, Governmental innovation policy, competitors, Science and Technological Parks, business incubators, scientific research institutions. It occurred, that competitors, Science and Technological Parks and business incubators take the leading role in the promotion and motivation of innovations' implementation*. Notably, that six operational Science and Technological Parks in Lithuania involve cooperation between industry and R\&D institutions and are oriented towards the development of new technologies, prototype products and creation of innovative hightech products. On the other hand, the role of scientific research institutions and governmental innovation policy was perceived as rather insignificant (Fig 2).

To conclude, real possibility to implement and apply innovations, provided by business incubators, Science and Technological Parks, and competition in the market serve as main driving forces of innovation process in Lithuania. The role of scientific institutions and state programs, as factors initiating innovations, is much less and does not compare to the role of factors mentioned above.

\section{Role of State aid}

The respondents were asked to indicate the main sources of information for new technologies*. The obtained data allow concluding that business companies obtain information directly from suppliers, in exhibitions and rely on tech- 


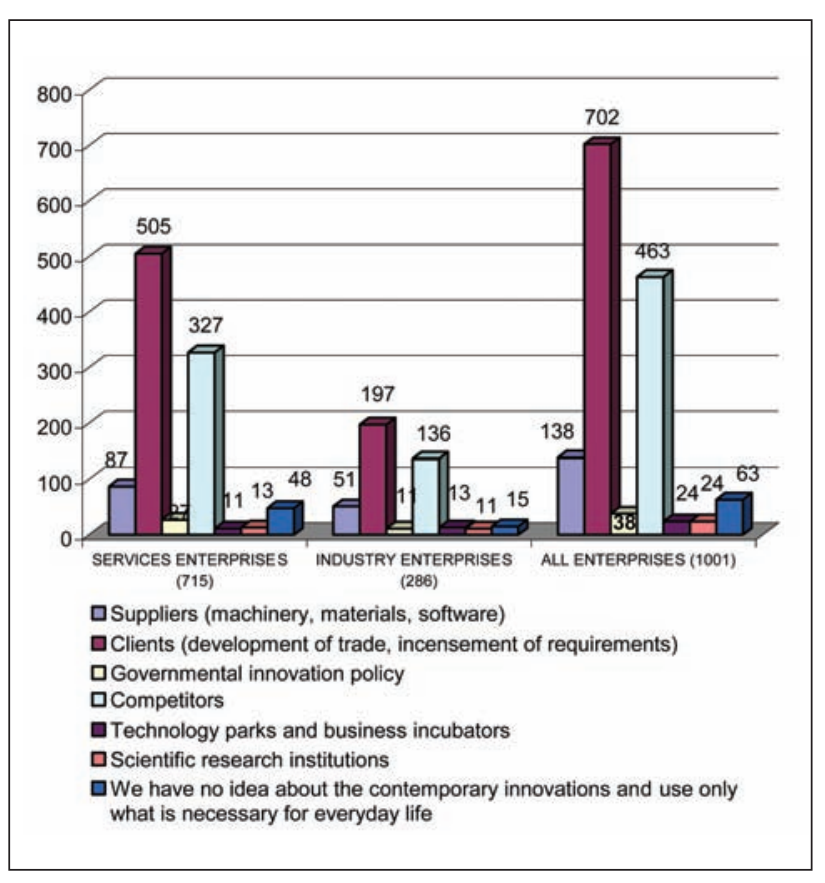

* Formulation of question was: "What promotes and motivates innovations' implementation in your enterprise?"

Fig 2. Factors fostering implementation of innovations

nology information data bases (Fig 3). On the other hand, state scientific and research institutions are not seen as the source of information for new technologies.

The responses of respondents to questions about factors retarding technology transfer process* let us reveal that business companies, especially in service sector, expect to be financed by external funds (as respondents indicated lack of latter ones). Insufficient profitability factor was followed by such factors as "lack of qualified employees" and "lack of information" (Fig 4).

Perceived efficiency of State policy

Responses to the following question are commensurate with assumption about unawareness of business companies about state programmes devised in order to facilitate implementation of innovations. The majority of business companies indicated the role of government as small, nonexistent or limited* (Fig 5)

Therefore, the companies indicated that they finance new projects from own funds and from the EU funds*. Only $12 \%$ of all respondents indicated governmental funds as the financial source of new projects (Fig 6).

$68 \%$ of respondents indicated that they have information about governmental innovations programmes* (Fig 7).

However, only $35 \%$ of all respondents indicated that they believe in the benefit of such programmes* (Fig 8).

Anyway, the connection between business sector and government is seen as weak. The majority of the companies which participated in the survey indicated this statement (Fig 9).

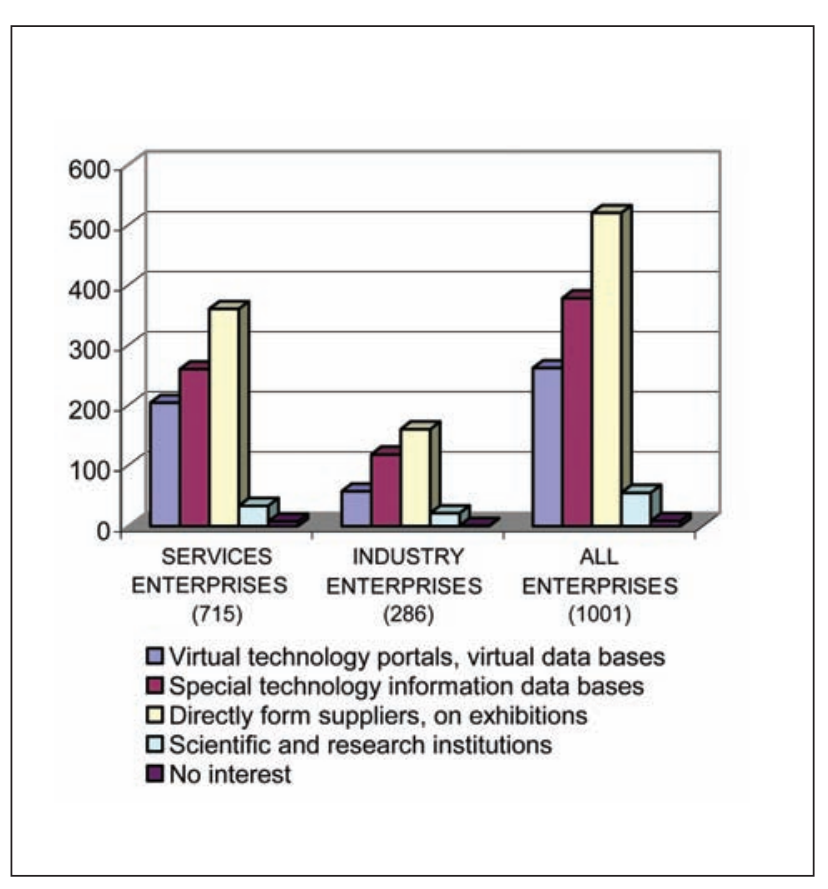

* Formulation of question was: "Where do you look for information about available new technologies?"

Fig 3. Main sources of information about new technologies

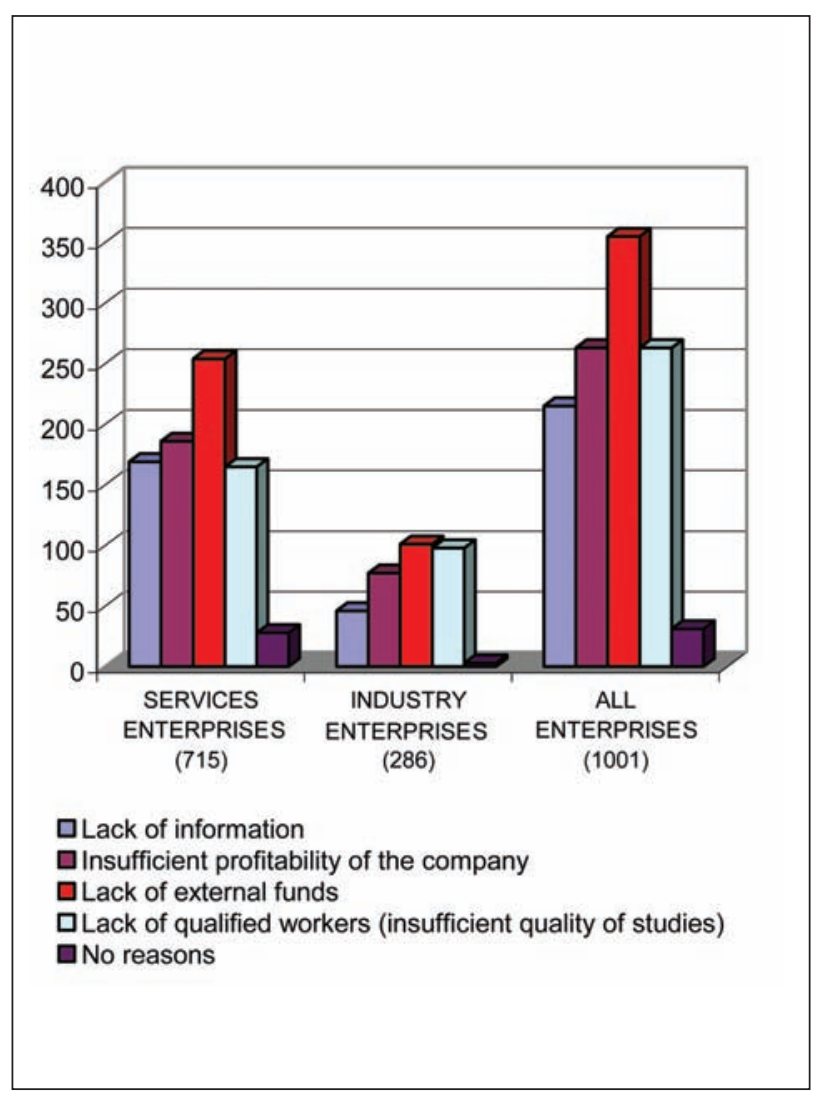

* Formulation of question was: "What impedes your company's direct participation in new technology implementation process?"

Fig 4. Factors retarding technology transfer process 


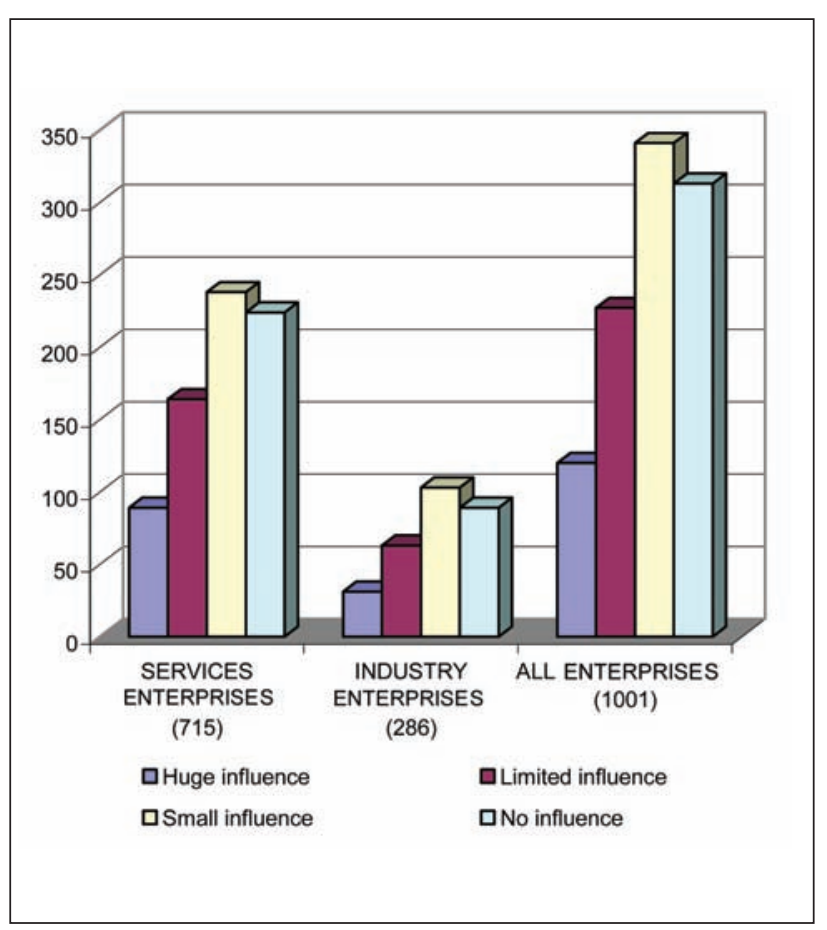

* Formulation of question was: "What is your opinion about governmental influence on establishment and implementation of technologies in your enterprise?"

Fig 5. Role of government in implementation of new technologies

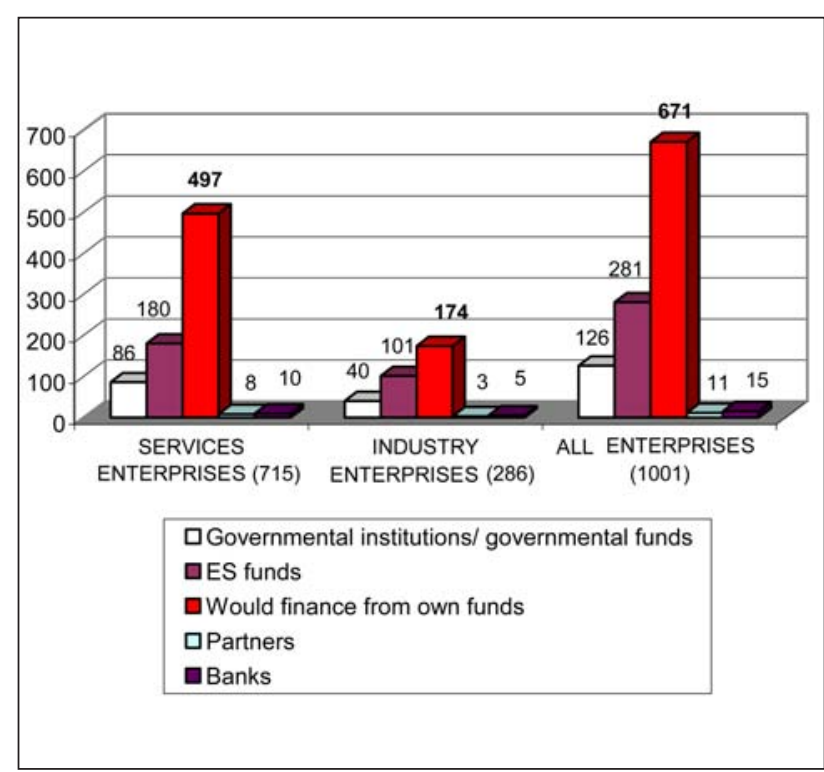

* Formulation of question was: "Where would you apply for financing of the project?"

Fig 6. Financial sources of new technologies

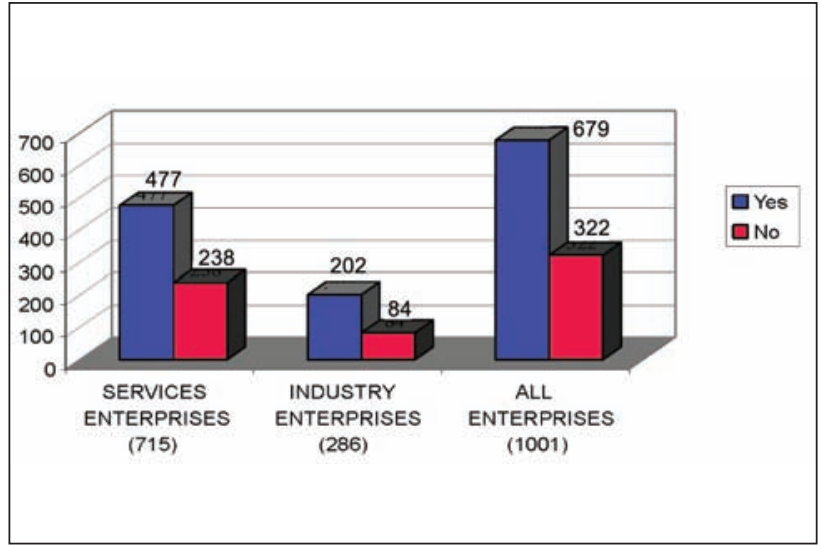

* Formulation of question was: "Do you know anything about governmental innovations programmes?"

Fig 7. The information available to companies about governmental innovations programmes

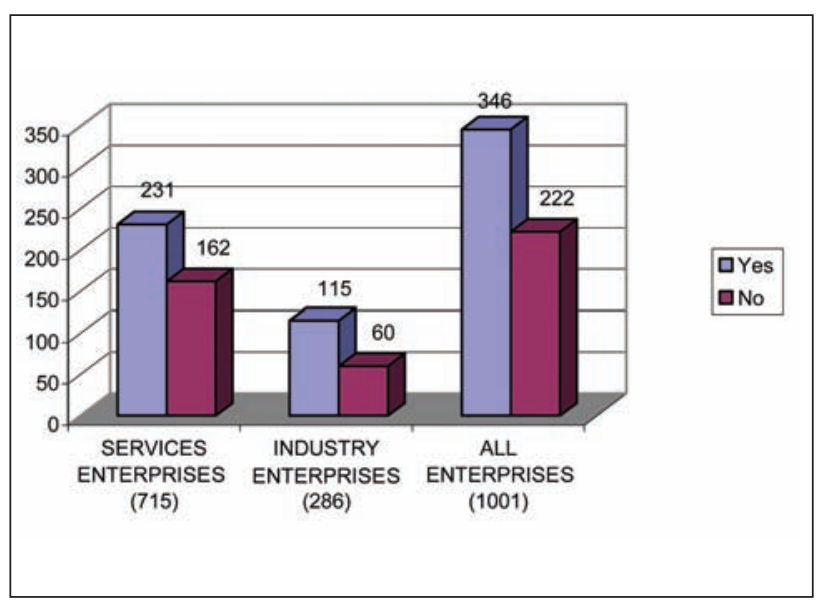

* Formulation of question was: Do you believe in the benefit of such programs?

Fig 8. The benefit of governmental innovations programmes

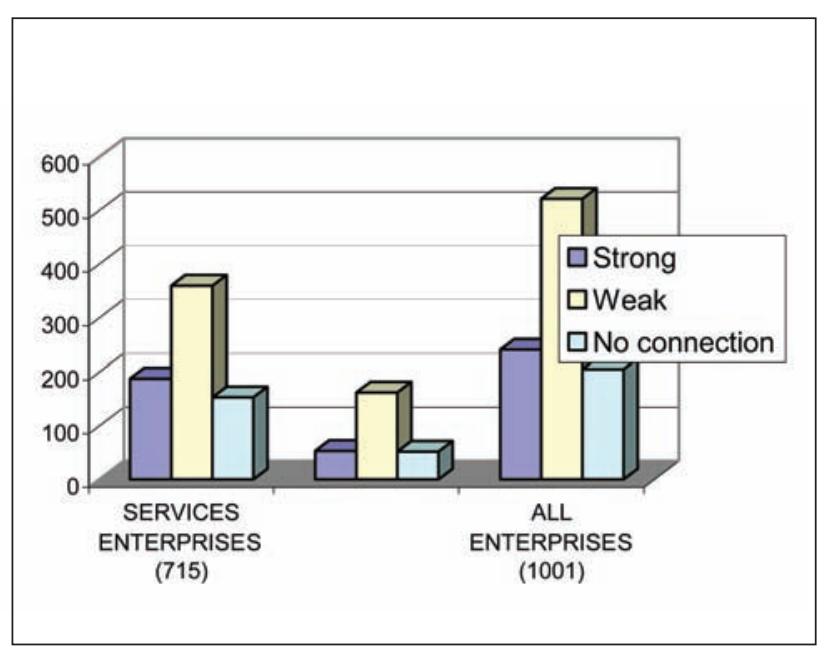

* Formulation of question was: How strong, in your opinion, is the connection between your business sector and government?

Fig 9. Connection between business sector and government 


\section{Conclusions}

The role of scientific institutions and state programs, as factors initiating innovations, is much smaller compared to availability of technology parks and business incubators, and existence of competitive business environment. Those latter factors serve as main driving forces of innovation process.

Business companies do not feel effects of active state policy in innovation fostering field and are not aware about available state and other external sources of financing. The survey revealed that ample programs are inefficient, what suggests, that implementation strategy of state policy has to be urgently reconsidered. Anyway, it is important to point out that the connection between business sector and government is seen as weak.

Business companies lack educated know-how susceptible employees. It is worth noting that the Lithuanian R\&D infrastructure is dominated by the public sector, which includes such institutions as universities, academies, research institutions, state research institutes, and state research institutions. However, Lithuanian science system is seen as the isolated one. Therefore Lithuania's public policy influencing formal development of innovations, through funding of the science base and research institutions and the provision of incentives for private $R \& D$, is inadequate. Hence, the country is lacking in a mechanism for influencing the capacity to develop new ideas.

\section{References}

1. European Trend Chart on Innovation. Annual Innovation Policy Trends and Appraisal Report, Lithuania 2004-2005. Available from internet: <http://trendchart.cordis.lu/ scoreboards/scoreboard2005/Lithuania.cfm>

2. SOLOW, R. A contribution to the theory of economic growth. Quarterly Journal of Economics, 1956, 70, p. 65-94.

3. WEITZMAN, M. Recombinant growth. Quarterly Journal of Economics, 1998, 113, p. 332-360.

4. FREEMAN, C. and SOETE, L. The Economics of Industrial Innovation. London, Printer, 1997.

5. GROSSMAN, G. M.; HELPMAN, E. Innovation and growth in the global economy. Cambridge, MA: MIT Press, 1991.

6. SCHUMPETER, J. A. The Theory of Economic Development: An Inquiry into Profits, Capital, Credit, Interest, and the Business Cycle. Harvard University Press: Cambridge, MA, 1934.

7. SCHUMPETER, J. A. Capitalism, Socialism, and Democracy. Harper: New York, 1942.

8. SCHUMPETER, J. A. Business Cycles: A Theoretical and Statistical Analysis of the Capitalist Process. McGraw-Hill: New York, 1939.

9. TEECE, D. J. Profiting from technological innovations: implications for integration, collaboration, licensing, and public policy. In The Competitive Challenge: Strategies for Industrial Innovation and Renewal. Teece DJ (ed). Ballinger: Cambridge, MA; 1987, p. 185-219.

10. MORAN, P.; GHOSHAL, S. Markets, firms, and the process of economic development. Academy of Management Review, 1999, 24, p. 390-412.

11. HIRSHHORN, R.; NADEAU, S.; RAO, S. Innovation in a knowledge-based economy: the role of government, 2000. Available from internet: $<\mathrm{http}: / /$ pacific.commerce.ubc.ca/kbe/ rao.pdfs

12. OECD, Managing National Innovation Systems, 1999. Available from internet: <http://cdnet.stic.gov.tw/ebooks/OECD/ 44.pdf>

\section{VYRIAUSYBĖS VAIDMUO DIEGIANT INOVACIJAS: LIETUVOS SITUACIJA}

\section{Manuela Tvaronavičienė, Renata Korsakienė}

\section{Santrauka}

Analizuojami veiksniai, skatinantys inovacijų diegimą Lietuvoje. Atliekant tyrimą, buvo atsižvelgta i apklaustų įmonių dydị ir ekonomikos sektorių. Autorès siekè ịvertinti Vyriausybès vaidmenį inovacijų kūrimo bei diegimo į šalies ekonomiką procese. Todèl analizuojamas valstybės vaidmuo, siekiama ịvertinti valstybės politikos efektyvumą. Straipsnio pabaigoje apibendrinami tyrimo rezultatai ir pateikiamos išvados. Atliktas tyrimas remiasi verslo įmonių apklausos rezultatais.

Reikšminiai žodžiai: inovacijos, Vyriausybè, valstybès parama, valstybès politika.

Manuela TVARONAVIČIENĖ. Dr, works as Professor at Vilnius Gediminas Technical University, Department of Economics and Management of Enterprises. Research interests: tax system's reforms in transition economies, investigation of legal tools of conditioning of business environment and factors stimulating growth processes in transition countries.

Renata KORSAKIENĖ. Dr, works as Associate Professor at Vilnius Gediminas Technical University, Department of Economics and Management of Enterprises. Research interests: strategic management, business organizations, innovations. 